\title{
The Evolution of Holmes, Holmes and Evolution
}

\author{
Jan Vetter $\dagger$
}

The occasion of these remarks is the one-hundredth anniversary of the publication of Holmes' The Common Law, but it is not so much his book as it is his later career that explains why we observe the occasion. The Common Law is a widely known book but one inore widely known than read, while perhaps it is more often read than understood. Unlike William Blackstone, who wrote an extraordmarily influential book before becoming an obscure judge, Holmes is a famous judge wlio wrote a difficult book. If lie had died shortly after finishing the book, as he thought lie might, ${ }^{1}$ it is very unlikely that we would be talking today about it or him. The prominence of the book owes a great deal to the reputation of the judge. It is also true, however, that The Common Law, togetlier witli a few essays, contains some marvelous aphorisms, a few pages altogether, that served to reinforce the reputation Holmes gained on the United States Supreme Court.

Just what Holmes' reputation ought to be has become problematic. For a long time the mention of his name seemed to require as if by reflex some such term as "master of jurisprudence." Fifty years ago Jerome Frank felt confident that Holmes was "one of the finest ideahists of our time,"2 and Cardozo described him as a "great Liberal" and "the great overlord of the law and its philosophy." 3 Compare the advice Holmes' current biographer, Grant Gilmore, gave the audience at the 1974 Storrs Lectures at Yale:

Put out of your mind the picture of the tolerant aristocrat, the great hiberal, the eloquent defender of our liberties, the Yankee from Olympus. All that was a myth, concocted principally by Harold Laski and Felix Frankfurter, about the time of World War I. The real Holmes was savage, harsh, and cruel, a bitter and lifelong pessimist who saw in the course of human life nothing but a contimuing struggle

$\dagger$ Professor of Law, Boalt Hall School of Law, University of California, Berkeley. B.A. 1956, LL.B. 1962, University of California, Los Angeles. This paper was presented at the Harvard Law School on November 5, 1981, as one of three 1981 Ohver Wendell Holmes Lectures.

1. See, e.g., 2 Holmes-Laski LetTERS 1019 (M. Howe ed. 1953) (“C[asanova]'s book did me good at a critical moment-just when I had got out ny Common Law and had some symptoms that for the moment I mistook for a funeral knell.").

2. Frank, Mr. Justice Holmes and Non-Euclidean Legal Thinking, 17 CORNell L.Q. 568, 570 n.5 (1932).

3. Cardozo, Mr. Justice Holmes, 44 HaRv. L. Rev. 682, 687, 691 (1931). 
in which the rich and powerful impose their will on the poor and weak. ${ }^{4}$

Although this is at the least forcefully stated, it does illustrate the marked tendency, which has gained strength over the last generation, to revise sharply, if not to reverse, the formerly dominant appraisal of Holmes.

It is not necessary to endorse Gilmore's view to see what he is driving at. There is a received tradition inuch like his description. It is clear also that Holmes was a deeply conservative person, quite unsympathetic to inost of the reforms advocated by the liberals whose praise of him made his reputation. We are left with the question how a man in inany ways so illiberal could have becoine a patron saint of liberal reform over inost of the first half of the twentieth century, and given that he did, why the present judgment should be so different. This is a question of the relation between Holmes and opinion, and an answer needs to explain both terms of the problem. In what follows I will sketch an account of the growth and decay of Holmes' standimg im opinion and then propose an interpretation of his position, based mainly on The Common Law and some other extrajudicial writing.

\section{The Evolution of Holmes}

In The Common Law there is a striking image of conscripts marched up to the front lime with bayonets in their backs. ${ }^{5}$ During the first half of the twentieth century, many years after the book was publislied, Holmes was himself gradually inducted into service on the liberal side in the twentieth century war over the role of judges in the American polity. Sometinue in the 1950's, twenty-odd years after his death, he was found no longer fit for service and finally released from duty.

Three main eleinents combined to form the picture of Holmes that took shape in liberal opinion. He was a rehable spokesman, often in dissent, for the right of legislative majorities to translate their preferences into law. These opinions were, as Felix Frankfurter put it, "the more significant in that, not infrequently, they come from a man who, as judge, enforces statutes based upon econounic and political theories which lie does not share and of whose efficacy in action he is skeptical."6 Holmes supplied a model of restraint in exercising the power of judicial review over the legislation of liberal reform. To continue the Frankfurter quotation, in a way unfair to Frankfurter himself, "The

4. G. Gilmore, The Ages of AMERICAN LAW $48-49$ (1977) (footnote omitted).

5. O.W. Holmes, The Common LAw 37 (M. Howe ed. 1963).

6. Frankfurter, Mr. Justice Holmes and the Constitution, 41 HARv. L. REv. 121, 153 (1927). 
judicial function here reaches its highest exercise." 7

Also, Holmes was seen as the preeminent defender of civil liberties. In Schenck v. United States ${ }^{8}$ he recorded two signal achievements. His opinion committed the Supreme Court to a view of the first amendment as bearing on pumshment for past speech as well as on prior restramt, and it succeeded in substituting the narrower standard of clear and present danger in place of the so-called bad tendency test. His dissents in Abrams v. United States ${ }^{9}$ and Gitlow v. New York ${ }^{10}$ together with Brandeis' concurring opinion in Whitney v. California ${ }^{11}$ served to focus discussion of free speech for a generation. Zechariah Chafee, Jr. classed Holmes with Milton, Erskine, and Mill in giving meaning to freedom of speech. ${ }^{12}$ Frankfurter said in 1938, "what Mr. Justice Holmes did during his thirty years on the Supreme Court to vindicate the claims of Anglo-American liberty through law has not been exceeded by the achievement of any judge."13

Third, the legal reahists during the 1920's and 1930's traced to Holmes the origin of their program for renovatimg American legal thought. Karl Llewellyn said that the realists all derived froin Holmes ${ }^{14}$ and declared that "Holmes, Holmes almost alone, has cracked open the law of these United States. The time-deep calcme crust is burst forever." 15 For Jerome Frank, Holmes was "the completely adult jurist," who had entirely given up the illusory search for an authoritative father to be found in mechamical jurisprudence. ${ }^{16} \mathrm{He}$ had been first to take a naturalistic view of law, as Machiavelli had of politics, had "imvented non-Euchdean legal thinking."17 Hessel Yntema attributed to Holmes a "great conception of rational legal science as the basis of law," a "valid" ideal, Yntema thought, still (im 1931) "imperfectly realized." 18 These three elements were fused in a hagiographic tradition, much of which is summed up in Henry Steele Cominager's book

7. Id.

8. 249 U.S. 47 (1919). The defeudants' enthusiasm for the opinion may have been tempered by the outcome of the decisiou, which was to affirm their convictions for violation of the Espionage Act.

9. 250 U.S. 616,624 (1919) (Holmes, J., dissenting).

10. 268 U.S. 652, 672 (1925) (Holmes, J., dissenting).

11. 274 U.S. 357, 372 (1927) (Brandeis, J., concurring).

12. Z. Chafee, Free Speech in the United States 509 (1941).

13. F. Frankfurter, Mr. Justice Holmes and the SUPREMe Court 86-87 (2d ed. 1961).

14. Llewellyn, Law and the Modern Mind: A Symposium, 31 Colum. L. Rev. 82, 84 n.1 (1931); see also Llewellyn, What Price Contract?-An Essay in Perspective, 40 Yale L.J. 704 n.* (1931) ("[Holmes'] work is the major foundation on which the realistic trends in jurisprudence rest.").

15. Llewellyn, Holmes, 35 Colum. L. Rev. 485, 487 (1935).

16. J. FrANK, LAW AND THE MODERN MIND 253 (1930).

17. Frank, supra note 2, at 570-72.

18. Yntema, Mr. Justice Holmes' View of Legal Science, 40 Y ALE L.J. 696, 703 (1931). 
of 1950, The American Mind. In celebrating Holmes' achievement as a legal scholar and his practice as a judge, Commager described him as master of a new type of jurisprudence needed to resolve "the conflict between fixed, mechamical concepts of law and dynamic, progressive ideas in politics." 19

As a portrait of Holmes this view resembles an El Greco paintmg-recognizable but distorted. It was, lowever, a photographic reproduction of the ideal judge of liberal opinion through the New Deal period. It was unade for use in conteinporary quarrels over judicial review, free speecli, and legal reasoning. Because it was historically contimgent in this way, the image of Holmes could change with a shift in the agenda of debate about judges.

A shift of this kind was underway by 1940, when Lon Fuller published an attack on legal positivisin that extended to Holmes. ${ }^{20}$ Legal positivisin Fuller described as an atteinpt to develop a concept of law imdependent of noral criteria; his arguinent was that the enterprise was self-defeating and destructive. Self-defeating because, in Fuller's view, it is in practice impossible to avoid soine confusion of law and norality, destructive because positivisin fails "to give a proftable and satisfying direction to the application of human energies in the law." 21 "Surely," he said, "the inan who conceives his task as that of reducing the relations of inen to a reasoned harmony will be a different kind of lawyer from one who regards his task as that of charting the behavior sequences of certain elderly state officials."22 Fuller saw the legal realists as American exponents of legal positivism. His sarcastic reference to the behavior patterns of elderly officials alluded to, annong other realist assertions, Karl Llewellyn's dictuin identifying law witlı what officials do about disputes, ${ }^{23}$ but also reached back to Holmes' remark, "The prophecies of what the courts will do in fact, and nothing more pretentious, are what I inean by the law." ${ }^{24}$ Fuller criticized as incoherent Holmes' advice to law students to consider the law from the point of view of a bad man, and lie partly blained Holmes' "enormous influence" for the positivist character, as Fuller believed, of American legal scholarship. ${ }^{25}$ This was telling criticism. The realists were at the tine giving ground to their opponents. This was partly because they

19. H. Commager, The American Mind 374 (1950).

20. L. Fuller, The LAW IN QUest OF ItSELF (1940).

21. Id. at 2.

22. Id. at 3-4.

23. See K. Llewellyn, The Bramble Bush 12 (1951 ed.) ("What these officials do about disputes is, to my mind, the law itself.") (emphasis in original; footnote omitted).

24. Holmes, The Path of the Law, 10 HaRv. L. Rev. 457, 461 (1897), reprinted in O.W. Holmes, Collected Legal Papers 167 (1920).

25. L. FULLER, supra note 20, at 117. 
had overstated their case. More important, they had done so in a way that failed to satisfy the newly aroused demand of American opinion that law reflect a moral order, a demand provoked in the late 1930's by the threatening appearance of Hitler and Stalin. ${ }^{26}$ To the extent that Holines seemed the progemitor of the legal realists, his fortunes declined with theirs.

That this occurred can be seen in a debate that took place in 1951 between Holnes' biographer Mark Howe and his colleague in the Harvard Law School Henry Hart. ${ }^{27}$ Howe undertook a defense of Holmes against what he described as:

a point of view which many lawyers have come, perhaps unconsciously, to share-a feeling not only that Holmes' philosophy of law was inconsistent with the highest traditions and aspirations of Western thought, but that his scale of moral and political values was badly suited to measure the needs of a progressive and civilized society. ${ }^{28}$

Howe attributed this view to Fuller; to refute it he focused, as Fuller had, on Holines' 1897 speech, The Path of the Law. ${ }^{29}$ Here, Holines had made a sharp distinction between law and morals, had introduced the bad man, from whom students were to take lessons, and had advanced his prediction theory of law. He had also advocated the use of law to reach dehiberately chosen social goals. Howe interpreted the speech as in the first place expressing rejection of stultifying nineteenth century orthodoxy under which law was held to possess a rigid, determinate logical and moral structure, in the second place as summoning lawyers and judges to take "responsibility to bring decisions into conformity with current standards of morality." 30

Hart was not persuaded. For argument's sake he was willing to grant that Holmes meant to advise lawyers and judges to rely on utilitarian ethics in shaping the law. But he maintained that Holines had also given a second, conflictimg message. By insisting on a division of law and morals, dramatized in the figure of the bad man who cares only for the law's sanctions, he lent powerful support to legal positivism. Hart agreed with Fuller that law and morality are inescapably tangled. Consequently, Holines' reduction of law to prediction of judicial action furnished "the signpost which so many have followed straight down the path to the deadly bog of behaviorisin." ${ }^{31}$ Hart went

26. See generally E. Purcell, The Crisis of Democratic Theory (1973).

27. Hart, Holmes' Positivism-An Addendum, 64 Harv. L. Rev. 929 (1951); Howe, The Positivism of Mr. Justice Holmes, 64 HARv. L. Rev. 529 (1951) [hereinafter cited as Howe, Positivism of Holmes]; Howe, Holmes' Positivism-A Brief Rejoinder, 64 HARv. L. REv. 937 (1951).

28. Howe, Positivism of Holmes, supra note 27, at 531.

29. Holmes, supra note 24.

30. Howe, Positivism of Holmes, supra note 27, at 542.

31. Hart, supra note 27, at 932. 
on to argue that Holmes in other ways had oversimplified the relation of law and morals. Morality was important in changing the law and in judging claims about what the law actually provides. ${ }^{32}$ But the connection Hart einphasized nost strongly had to do with "[t]he moral claims of settled law in a constitutional deinocracy." 33 His point was that law that "is the due result of a fair procedure of institutional settlement and is subject to change by further and fair procedure" has a moral claim to compliance. ${ }^{34}$

This showed anxiety over the relation of legal thought and obedience to law. Here as well as elsewhere Hart carried forward a theme of Fuller's, which Fuller had explicitly linked to the advent of Hitler's regime in Germany. ${ }^{35}$ The external, behavioral approach to law, which Holmes evidently endorsed, threatened the legal framework of society by undermining its moral basis. As the realists had employed that approach, it was designed to serve legal reform by exposing fundamental flaws in the legal reasoning used to justify doctrine they opposed. But this proved too drastic a remedy. They apparently counted on social science or utilitarian ethics to provide answers to legal problems. However, the checks they drew on those sources went unpaid for insufficient funds. Hence, what the realists seemed to have achieved was to put in question the possibility of justification in legal argunnent. They did compel the concession, practically universal since the end of World War II, that logic, in the sense Holmes nneant, is not the life of the law. With that point granted, it becaine an important task of American legal scholarship to redeem law by explaining how judges should decide cases. This has been attempted at first by providing criteria of fairly determined institutional settlement, ${ }^{37}$ more recently either by claiming for the courts a prerogative to enforce moral values or by casting economic analysis in the leading role. ${ }^{38}$ On these issues Holmes either has little to contribute or has to be counted against the effort. In the face of widespread if not general agreement that legal
32. Id. at 936 .
33. Id. at 937 .
34. Id.
35. L. FULLER, supra note 20, at 120-28.
36. O.W. HOLMES, supra note 5, at 5:

It is something to show that the consistency of a system requires a particular result, but it is not all. The life of the law has not been logic: it has been experience. The felt necessities of the time, the prevalent moral and political theories, intuitions of public policy, avowed or unconscious, even the prejudices which judges share with their fellow-mcn, have had a good deal more to do than the syllogism in determining the rules by which men should be governed.

37. This can be seen as a major theme of H. HARt \& A. SACKs, The Legal Process: Basic Problems IN THE MakING and Application of LAW (tent. ed. 1958).

38. See R. DWorkin, TAKing Rights Seriously (1977); R. Posner, ECONOMIC ANALysis OF LAW (2d ed. 1977). 
reasoning should, and could, be supported in some way, he slipped into irrelevance on this subject. He was historically significant for his contribution to the subversion of an untenable orthodoxy; he gave no help to the succeeding effort at reconstruction.

In the exchange between Hart and Howe Holmes appears for the last time as a live influence, important to attack or defend for purposes of current controversy. It was not just that the focus on lcgal thought shifted. The Supreme Court revolution of 1937 destroyed economic due process as a barrier to reform legislation. This is how an expert observer described the effect of the revolution from the perspective of 1951:

But as late as 1936 the Court was still holding that labor relations in the coal industry only affected interstate commerce "indirectly," and therefore were not subject to the power of Congress, that the ainount of cotton produced in the United States was only of local concern and therefore not subject to federal control; and that the fixing of minimum wages for woinen violated the due process clause. These decisions, and the doctrines for which they stand, now seem antediluvian. Although they hardly can be said to be of great antiquity, they have a nuch less modern ring and infinitely less authority thau Gibbons v. Ogden, decided in $1824 .^{39}$

Heroes require battles. So long as Holmes' position on judicial review was put forward in dissent, it necessarily took a prominent place in liberal opinion. Once that position became axiomatic in the Supreine Court's practice, it lost its hold on public attention.

Of course, nothing of the kind happened to civil liberties issues. From the time of the Second World War to the present, these account for a great deal of the controversy over the place of courts in American life. Nevertheless, there has not been much use nuade of Holmes. His chief contribution-the clear and present danger test of punishable speech-no longer survives. The Supreme Court was not willing to apply it to certain questions of free speech that became important in the 1940's and 1950's-labor picketing and obscemity. On the first of these questions the Court settled on the test whether the picketing amied to produce a substantive evil the state could prevent, ${ }^{40}$ on the second the Court has tried to provide criteria of obscenity that will identify it as a category of unprotected speech. ${ }^{41}$ When a first aniendment conception of defamation appeared in the 1960's, it took the form of protecting

39. Stern, The Problems of Yesteryear-Commerce and Due Process, 4 VAND. L. Rev. 446, 447 (1951) (footnotes omitted).

40. See, eg., International Bhd. of Teamsters, Local 695 v. Vogt, Inc., 354 U.S. 284 (1957); Giboney v. Empire Storage \& Ice Co., 336 U.S. 490 (1949).

41. See, e.g., Miller v. California, 413 U.S. 15 (1973); Roth v. United States, 354 U.S. 476 (1957). 
damaging speech about public figures that was not culpably false. ${ }^{42}$ Also, the Court came increasingly to rely on the overlapping notions of vagueness, overbreadth, and least restrictive means across a broad spectrum of cases-those dealing with loyalty oaths for example. ${ }^{43}$ Rather than a skeleton key that opens all doors, clear and present danger came to be seen as an approach to only a restricted range of free speech problems, essentially those of advocacy of illegal action. Even here, it was never clear how to use the test when a statute was attacked on its face rather than as applied or when a statute prohibited speech itself rather than conduct that speech might proinote. ${ }^{44}$ Moreover, the test became shapeless with its transformation, in Dennis $v$. United States, into the question "whether the gravity of the 'evil,' discounted by its improbability, justifies such invasion of free speech as is necessary to avoid the danger."45 When in 1969 the Supreme Court returned to what was by then seen as the narrow category of speech advocating illegal action, the canonical formulation "clear-and-present-danger" was abandoned in favor of the statement that punishable advocacy "is directed to inciting or producing imminent lawless action and is likely to incite or produce such action."46

At the same time that clear and present danger shrank in relation to the expanding domain of free speech, civil liberties came to include inuch more than speech. Since Holmes resigned from the Court, the development of constitutional norms has remade criminal procedure. Although Holmes could once describe an appeal to the equal protection clause as "the usual last resort of constitutional arguments,"47 equal protection has since become the Constitution's most formidable weapon, before which ranks of statutes fall. A right of privacy has been discovered in the Constitution's nurky depths, with the result that the states cannot prohibit abortion except within very restricted limits. ${ }^{48}$ The right to a hearing in connection with deprivation of liberty or property interests has been inuch enlarged. ${ }^{49}$ Increased attention to the

42. See, e.g., Curtis Publishing Co. v. Butts, 388 U.S. 130 (1967); New York Times v. Sullivan, 376 U.S. 254 (1964).

43. See, e.g., Keyishian v. Board of Regents, 385 U.S. 589 (1967); Elfbrandt v. Russell, 384 U.S. 11 (1966); see also United States v. Robel, 389 U.S. 258 (1967) (striking down provision of Subversive Activities Control Act of 1950 that prohibited menibers of Communist organization from working in defense facilities).

44. See Linde, "Clear and Present Danger" Reexamined: Dissonance in the Brandenburg Concerto, 22 StaN. L. Rev. 1163 (1970).

45. 341 U.S. 494, 510 (1951) (quoting United States v. Dennis, 183 F.2d 201, 212 (2d Cir. 1950) (L. Hand, J.)).

46. Brandenburg v. Ohio, 395 U.S. 444, 447 (1969) (footnote omitted).

47. Buck v. Bell, 274 U.S. 200, 208 (1927).

48. Roe v. Wade, 410 U.S. 113 (1973).

49. See, e.g., Goss v. Lopez, 419 U.S. 565 (1975); Wolff v. McDonnell, 418 U.S. 539 (1974); Goldberg v. Kelly, 397 U.S. 254 (1970). 
religion clauses of the first amendment has led to a constitutional ban on school prayer. ${ }^{50}$ As civil liberties grew into the more inclusive idea of civil rights, Holmes lost his position as a dominant figure taking up much of the foreground and, greatly diminished in size, seemed to recede into a small corner.

Moreover, when the historical record came to be reexamined through the wider focus the concept of civil rights provides, Holmes appeared indifferent if not hostile to civil rights. This was the conclusion of just such an examination conducted by Yosal Rogat in the early 1960's. After reviewing twenty-five nonunanimous civil liberties cases, most of which involved constitutional claims made by aliens or blacks, Rogat decided that "the accepted image of Holmes as uniquely libertarian owes inore to fantasies unloosed by the attractiveness of his personality than to the realities of his career." ${ }^{\text {" } 1 ~ W h e n ~ R o g a t ~ t r i e d ~ t o ~}$ come closer to reality, he said:

Nowhere in any of the cases that we have considered did Holmes help in framing a remedy to secure a constitutional right. He did not develop further any inchoate right or liberty, or broaden the scope of those which were already established. Nor did he ever perceive new interests that were relevant to the determination of rights and liberties.

Instead, he habitually upheld government action by pointing to the most general powers that government had already exercised, giving little indication of how the Court might determine the limits of those powers, and sometimes leaving it unclear whether any such limits existed. $^{52}$

Rogat has had successors who have nuore reinforced than refuted his judgment. Thus the writer of a new study of free speech in the late nineteenth and early twentieth centuries observes that "[r]ecent legal scholarship has so heavily criticized Justice Holmes that his once unchallenged reputation as a civil hibertarian has been replaced by a new orthodoxy emphasizing his indifference or hostility to civil liberties, particularly before his dissent in Abrams $v$. United States." 53

Throughout, the dominant tone of writing on Holmes has been evaluative, judgmental. But while once it aimed usually to praise, its objective lately has often been to blame. Now as then the literature commonly reflects a conception of the ideal judge; the fall in Holmes' reputation discloses a change in that conception at least as clearly as it illuminates Holmes. This shows in what seems to me, Howe's unfinished biography apart, the most interesting study of Holmes we have-

50. School Dist. v. Schempp, 374 U.S. 203 (1963); Engel v. Vitale, 370 U.S. 421 (1962).

51. Rogat, Mr. Justice Holmes: A Dissenting Opinion, 15 STAN. L. Rev. 254, 308 (1963).

52. Id. at 305-06.

53. Rabban, The First Amendment in Its Forgotten Years, 90 YALE L.J. 514,580 n.357 (1981). 
Yosal Rogat's 1964 article The Judge as Spectator. ${ }^{54}$ In the tradition represented by Frankfurter, Holmes' single most distinguishing feature had been his skepticism. His reservations in the face of dogma, his doubt of the credentials of behef, plainly evident in his off-duty speculations about large philosophical questions, were thought to inform his judicial practice. To this was traced his willingness as a judge to suppress his own views of the merit of reform legislation in favor of its constitutionality and to insist-in the Abrams and Gitlow cases-that government adopt the same laissez-faire posture toward the marketplace of ideas that he exemplified in his philosophical ineditations. ${ }^{55}$ Rogat puts this by saying that Holmes made the perspective of "detached spectator ... the very basis of judicial greatness." term "judicial greatness" refers here to the traditional estimate of Holmes, not to Rogat's own view. For "skepticism" as the aptly descriptive word for Holmes' attitude Rogat substituted "detachınent." $\mathrm{He}$ argued that "Holmes was not skeptical about any of the practical issues involved in judicial decision," 57 that on the contrary Holmes confidently believed that much of the legislation he voted to uphold was entirely misdirected. He voted as he did "not because he was uncertam about the merits but because he deemed his view of the merits to be irrelevant." ${ }^{8}$ Holmes was not merely "disinterested"; he was also "un interested." "To "To a reinarkable degree," Rogat said, "Holmes simply did not care." ${ }^{60} \mathrm{He}$ was fundamentally an observer, but in performing the role of judge with the psychological detachinent of a spectator, lie exhibited a paradox. In Rogat's words, "Holmes retreated into participation; he withdrew into public responsibilities." 61 This perception of Holmes led Rogat to ask whether a "minimum of involvement" is required of a judge, whether Holmes was "sufficiently engaged." 62 The answer was unfavorable to Holmes. His lack of commitment produced in him a techırician's view of a judge's role. Acting

54. Rogat, The Judge as Spectator, 31 U. CH1. L. Rev. 213 (1964).

55. The marketplace reference is to Abrams v. United States, 250 U.S. 616, 630 (1919)

(Holmes, J., dissenting):

But when men have realized that time has upset many fighting faiths, they may come to believe even more than they believe the very foundations of their own conduct that the ultimate good desired is better reached by free trade im ideas-that the best test of truth is the power of the thought to get itself accepted in the competition of the market, and that truth is the only ground upon which their wisles safely can be carried out. That at any rate is the theory of our Constitution.

56. Rogat, supra note 54, at 233.

57. Id. at 251.

58. Id. at 254 .

59. Id. at 245 (emphasis in original).

60. Id at 255 .

61. Id at 243 .

62. Id. 
as a technician, the man who once described himself as "the supple tool of power"63 allowed power to establish the premises from which he determined legal rights. In Rogat's view this explained Holmes' deference to the legislature: "He seemed to think that in his day numbers (i.e., the legislature) equaled power, and he saw no alternative to accepting the crowd's desires, no matter how wrong he thought them."64 The result was that "Holmes could fail to apply constitutional limitations; that he thought of the Supreme Court as inore of an instrument for implementing the irresistible demands of the dominant forces in society" than as a potential check on those desires." ${ }^{25}$ Rogat summed up his opinion of Holmes, and of his admirers, in this way:

In considering Holmes it is necessary, no less than in [Henry] James' case, to refer to "The Legend of the Master." Primarily interested in the common law, as a judge Holmes greatly influenced only constitutional law. Remarkably dogmatic, Holmes exemplifies "humility." Fatalistic, mistrustful of reason, obsessed with the ubiquity of force, Holmes is nevertheless classified with John Dewey. Generally indifferent to civil biberties interests, Holmes is regarded as their champion. Unconcerned with contemporary realities, Holmes inspired a school of legal "realists." Uninvolved with the life of his society, Hohnes affected it profoundly. The apotheosis of Holmes defeats understanding. Just as it is possible to take another view of those traits that have been held to be the source of Holmes' greatness, so it is possible to take another view of the praise intended by Holmes' most distinguished follower [Frankfurter]: "[T] he significance of his genius would evaporate in any analysis of specific decisions."

This verdict seems to me ahistorical. It leaves out of account the reasons that explain why liberals like Frankfurter and Laski made a hero of Holmes in his own time. It applies standards quite different from theirs that were current at the time the article was published. At least from Lochner v. New York ${ }^{67}$ in 1905 to NLRB v. Jones \& Laughlin Steel Corp. ${ }^{68}$ in 1937, the chief liberal demand on the Supreme Court was that it ratify reform legislation concerned more than any other single issue with regulation of the employment relation under industrial capitalism. After World War II, when that demand had been satisfied, liberal opinion sought and increasingly received from the Court another kind of performance. In place of deference to legislative judg-

63. 1 M. Pusey, Charles Evans Hughes 287 (1951).

64. Rogat, supra note 54, at 249.

65. Id. at 250 (footnote omitted) (quoting $2 \mathrm{M}$. Howe, Justice Oliver WeNDell Holmes: The Proving YeArs, 1870-1882, at 57 (1963)).

66. Id. at 256 (footnote omitted) (quoting F. FrankFuRTER, MR. JUSTICE HOLMES AND THE SUPREME COURT 29 (1939)).

67. 198 U.S. 45 (1905).

68. 301 U.S. 1 (1937). 
ment, there appears aggressive enforcement of constitutional limitations derived from an enlarging conception of the Bill of Rights. Even inore important, there is a reformulation of the equal protection clause to incorporate in the Constitution the moral imperative of racial equality that crystallized as the deepest liberal commitinent of the period. Rogat's poimt really is that Holmes was not a fit nember of the Warren Court as of 1964. The disparagement of Holmes depends upon historically contingent criteria that imply and defend the liberal image of the ideal judge at that time under conservative attack. There is not so much a quarrel with Holmes as there is a dispute about him, a conflict of generations the outcome of which is a revised liberal attitude toward constitutional law.

Holmes has figured in the liberal tradition as constitutional oracle and as forebear of legal realism, but he was also an expositor of the common law. By far the fullest statement of his position in this role is in the book of that title, which expresses opinions that he adhered to with only modest change for the rest of his life. Here, a paradox appears. Holmes' general views nourished twentieth century reforms of the common law quite opposed to the particular doctrimal positions he endorsed. On one hand he declared that "[t]he life of the law has not been logic: it has been experience." $69 \mathrm{He}$ argued that judicial decisions must rest ultimately on "legislative primciples," that judgments should be based on "broad considerations of policy."70 As this was absorbed in the current of liberal reform of law, it came to be understood as recommending that judges govern decision by pragmatic evaluation of practical consequences. In the ideology of reform, the status quo was allegedly supported by deductive reasoning from first principles laid down as axioins-that is, by "logic." On the other hand doctrines of tort and contract that Holmes advocated turn out to be orthodox positions that reformers attacked.

One of the main propositions Holmes tried to establish in his lecture on trespass and negligence was that the common law typically nade fault a condition of liability. He put this forward in opposition to the view that "a man acts at his peril,"71 and he labored to reduce toward the vanishing point the cases in which the common law imposed liability for injury regardless of fault. This effort was not entirely convincing as a statement of the law current in 1880, but Holmes did conduct a brilliant discussion of negligence as behavior "blamewortlyy in the average inan, the man of ordinary intelligence and prudence."72

69. O.W. HolmES, supra note 5 , at 5 .

70. Id. at 64 ; see also id. at 85 .

71. Id. at 67 (emphasis omitted).

72. Id. at 87. 
This has to be counted a remarkable success because it crystallized the conception of negligence that became dogma (reflected in section 285 of the First Restatement of Torts) and remaims dominant. But tort law in the twentietli century has slowly inoved away from the view that the law shifts losses only from innocent victims to blameworthy injurers. Rather, the law has been seen increasingly as a device for distributing the losses of accident victims over large classes, through imsurance or the price of products sold by the injurer ${ }^{73}$ This moveinent has enjoyed only limited success to date, but its tendency, and in the fields of workers' compensation and of products hability its achievement, encompasses strict liability. It is the position favoring strict liability that, at least until recently, has claimed justification on broad grounds of policy.

Holmes saw contract as the regime of agreement. On his view the only function of law within this domain was to support private agreements; the parties were sovereign, there was no room for state-imposed duties, tort and contract were mutually exclusive categories. The other main elements of his conception of contract were: imsistence on "consideration," itself sharply restricted to bargained exchange; an insurance view of enforceable promises; and the so-called objective theory. The first of these made enforceability dependent upon a relation between promise and consideration, with the necessary relation understood as one of "reciprocal conventional inducement."74 The consideration for the promise, which might be another promise, had to be sought as exchange for the promise.

Holmes' insurance view of contract can perhaps be easily introduced by adverting to a distinction inade by Pothier, the French author whose writing on contract was influential in nineteenth century England and America. Pothier divided contracts into cominutative agreements, in which the parties make an exchange, and aleatory agreements, in which compensation is given for assuming a risk. ${ }^{75}$ Holmes, ever alert to the possibility of a wider generalization, saw that all executory contracts could be conceived as undertakings to bear risk. As Holmes put it, "An assurance that it shall ram to-morrow, or that a third person shall paint a picture, may as well be a promise as one that the promisee shall receive froin some source one hundred bales of cotton, or that the promisor will pay the promisee one hundred dollars."76

73. For a fairly early, clear statement of this view, see James, Accident Liability Reconsidered: The Impace of Liability Insurance, 57 YALE L.J. 549, 549-5I (1948).

74. O.W. Holmes, supra note 5, at 230.

75. 1 R. Pothier, a Treatise on the Law of Obligations, or Contracts $\$ 13$ (W. Evans trans. 3d Am. ed. 1853). The passage is also translated in Gordley, Book Review, 89 HARV. L. Rev. 452, 459-60 n.10 (1975) (reviewing G. Gilmore, The Death of Contract (1974)).

76. O.W. HOLMES, supra note 5 , at 234. 
The promisor's power to control the promised event, or his lack of power, did not affect the matter.

With the objective theory Holmes aimed to combat the view that contracts inhered in converging wills, in a subjective neeting of the minds of the parties. He argued that instead questions of formation and interpretation depended on the conventions of language, independent of what the parties, or either of them, may have had in mind. In The Common Law this came out nost clearly in the discussion of Raffles $v$. Wichelhaus. ${ }^{77}$ In this classic parable of contract law the parties had agreed to a sale of cotton to be shipped from Boinbay to Liverpool, "to arrive ex Peerless." Two ships of that name sailed from Bombay-one in October, the other in Deceinber-and the second carried the cotton. When the buyer was sued for refusing to accept the shipinent, he clamied that he had imtended the first Peerless, and this was held a sufficient defense. The decision can be read, indeed is most plausibly read, as resting on the subjective theory: the parties' minds had not inet on a condition of the contract. Holmes attacked this interpretation. "The law has nothing to do," he said, "with the actual state of the parties' minds. In contract, as elsewhere, it must go by externals, and judge parties by their conduct. . . . The true ground of the decision was not that each party meant a different thing froin the other, . . . but that each said a different thing."78 The same point is made more clearly still in a later essay of Holmes', The Theory of Legal Interpretation. ${ }^{79}$ Speaking of interpreting a contract, he said:

Even the whole document is found to have a certam play in the joints when its words are translated into things by parol evidence, as they have to be. It does not disclose one meaning conclusively according to the laws of language. Thereupon we ask, not what this man meant, but what those words would mean in the mouth of a normal speaker of English, using them in the circumstances in which they were used, and it is to the end of answermg this last question that we let in evidence as to what the circumstances were. But the normal speaker of English is merely a special variety, a hiterary form, so to speak, of our old friend the prudent man. He is external to the particular writer, and a reference to him as the criterion is simply another instance of the externality of the law. ${ }^{80}$

Certain typical consequences followed from these features of the Holmesian contract system. The rigid conception of contract as strictly a function of agreement enforceable only in the presence of a tightly

77. 159 Eng. Rep. 375 (Ex. 1864).

78. O.W. HOLMES, supra note 5, at 242.

79. Holmes, The Theory of Legal Interpretation, 12 HARv. L. REv. 417 (1899), reprinted in O.W. Holmes, supra note 24, at 203.

80. Id. at 417-18, reprinted in O.W. HoLMES, supra note 24, at 204. 
defined version of consideration implied a narrow range of obligation, minimizing reliance and restitution as bases of liability. The objective theory and the view of enforceable promises as undertakings to insure entailed a narrow range of defenses once a contract was formed. Because contract depended on agreement conceived as a bargain for the assumption of certain risks, damages for breach excluded compensation for mjury beyond the risk msured. Thus Holmes rejected the suggestion of Hadley v. Baxendale ${ }^{81}$ that a promisor's knowledge of extraordinary or unusual injury resulting from breach of contract could increase damages; the promisor was liable only for the consequences of breach that he had agreed to underwrite. ${ }^{82}$ At the same time the notion of contract as insurance of the promised event translated into the expectation measure of dainages. Finally, the dependence of meaning on conventions of language instead of subjective understanding tended to make issues of interpretation seem questions of law for the judge rather than jury questions of fact.

Once again, positions that Holmes adopted were incorporated in a semi-official statement of the law. Williston's treatise on contract and the First Restatement of Contracts emphasized promise as the basis of obligation, embraced the objective theory and the view of consideration as bargained exchange, and favored the expectation measure of damages. As in tort law, however, these formulations became the target of effective criticism. They may now serve as a point of reference to measure the extent of change. By that ineasure there has taken place a considerable extension of liability beyond the point of breach of proinise supported by consideration. This has been achieved by relaxing Holmes' restrictively defined concept of consideration into a diffuse notion of vaguely articulated good cause for a promise, also by imposing liability where there has been reliance on a promise or where a benefit has been conferred that was not intended as a gift, sometimes without any promise. The parties have had to share authority witl the state; the law soinetimes attaches duties to a contract, as with implied warranties, soinetimes strikes out terms actually agreed to, as with disclaimers of warranty, and often intervenes to salvage contracts by supplying missing terms. Damages doctrime has been reshaped: consequential or even punitive damages may be given, while at the same time reliance and restitution measures have grown at the expense of damages protecting the expectation interest. Promise much less nearly monopolizes obligation; liability based on conferring a benefit or incurring detriment by rehance has expanded and come to seem more persuasive. Actual human beings appear in judicial opimons more often

81. 156 Eng. Rep. 145 (Ex. 1854).

82. O.W. HolmEs, supra note 5, at 236-37. 
than the prudent man. These developments reflect a partial convergence of contract and tort. Contract, like tort, has been more and more perceived as an instrument of regulation, of social control, threatening to displace the older view of contract as a ineans of supportimg private ordering. 83

As the law of tort and contract illustrate, two diverging traditions have competed im American law during the twentieth century. It would be a mistake to think of them as opposing armies lined up opposite each other in military formation, with all participants wearmg the uniform of one side or the other. It comes nearer the truth to imagine a continuuin, with people at opposite ends sharing a good deal in common with each other while those close to one another occasionally fall into quarrels and debates. Individuals sometimes changed position along the line over time; for example, Roscoe Pound moved to the right, Harlan Fiske Stone to the left. Measured agaimst some larger scale of conceivable disagreement, a fairly short line connected the most extreme positions taken in American law. However, the line could extend or shift, as it did with the advent of the Depression and the New Deal. Contrastimg clusters of attitudes marked the foci of the divergent halves of the line, which were in political terms liberal and conservative. On the conservative side appeared a view of law as facilitatimg private ordering, resort to a fornal and deductive style of legal reasoning as exemplified in treatises and restatements, and support of a strong version of judicial review to protect the existimg distribution of entitlements. This was met on the liberal side by a conception of law as an instrument of social control. Associated with this was an allegedly scientific, inductive style of legal reasoning guided by considerations of policy and attentive to the consequences of legal intervention. This was understood to muply at least mildly redistributive aims and led to advocacy of a weak version of judicial review of social and economic legislation.

What is striking is that Holnes stood on both sides of the divide between liberal and conservative. As a rule he disliked redistributive programs like those favored by the Progressives, and he held strongly to doctrines of private law whose consequences reformers considered pernicious. As he said in The Common Law, "State imterference is an evil, where it cannot be shown to be a good."84 He could not often be convinced there was any benefit to be had in state regulation that went beyond the views of tort and contract he had endorsed in The Common Law. His correspondence makes clear that he admired the magnates of

83. For a review of these developments, see G. GILMORE, THE DEATH OF CONTRACT 55-103 (1974).

84. O.W. Holmes, supra note 5, at 77. 
the Progressive period. Their wealth he thought only a small premium charged for performing the social function of effecting the most efficient distribution of goods and services. ${ }^{85} \mathrm{He}$ beheved that, as he put it, "the crowd now has substantially all there is." 86 On occasion he set out these opinions in ferocious terms. "[I]f there is a form of speech for which I have less sympathy than another," he wrote, "it is talk about 'exploitation,' as a hostile characterization of modern commercial life, and an inplication that dommant brains are to blame. I think it is drivelling cant and I have a standing war with my dear friend Laski, as to his passion for Equality, with which I have no sympathy at all."87 Sociahist writing he considered "drool." 88 As a convinced Malthusian he could say:

I think it a manifest humbug to suppose that even relative universal bliss is to be reached by tinkering with property or changing forns of government so long as every social improvement is expended in increased and unchecked propagation. I shall think socialisin begins to be entitled to serious treatment when and not before it takes life in hand and prevents the continuance of the unfit. ${ }^{89}$

At the same time he was, as we have seen, the sponsor of an instrumentalist style of judicial decisionmaking and progemitor of legal realism, also the exponent of a relaxed standard of judicial review that posed no barrier to reform legislation.

Holmes' hiberal admirers dealt with his apparent contradictions in various ways. Jerome Frank, for example, ordinarily ounitted to notice them..$^{90}$ Others, like Harold Laski and Morris Cohen, acknowledged

85. See O.W. Holmes, Economic Elements, in Collected Legal PAPERs, supra note 24, at 279-80. For Holmes on the railroad tycoon Jaines J. Hill, see, e.g., 1 Holmes-LASKI LeTTERS, supra note 1, at 373-74; 1 HolmEs-Pollock LeTTERS 166-67 (M. Howe ed. 1941).

86.

My hobby is to consider the strean of products, to omit all talk about ownership and just to consider who eats the wheat, wears the clothes, uses the railroads and lives in the houses. I think the crowd now has substantially all there is, that the luxuries of the few are a drop in the bucket, and that unless you inake war on moderate comfort there is no general economic question.

I HOLMES-POLLOCK LETTERS, supra note 85, at 124.

87. Justice Oliver Wendell Holmes: His Book Notices and UnCollected LeTters AND PAPERS 197 (H. Shriver ed. 1936) [hereinafter cited as BooK NotICES].

88. See I HOLMES-LASKI LeTTERS, supra note 1 , at 96 ("I never read a socialist yet from Karl Marx down, and I have read a number, that I didn't think talked drool.").

89. BooK Notices, supra note 87, at 181. For Holmes" view of Malthus, see, e.g., id. (“I believe that Malthus was right in his fundamental notiou, and that is as far as we have got or are likely to get in my day."); id. at 153 ("A century ago Malthus ran his sword through fallacies that one would have thought inust die then and there, but men didn't like to believe him, and the humbugs that he killed are as alive as ever today.").

90. The idolatry of Holmes displayed in J. FRANK, supra note 16, suggests that Frank found in Holmes what he worshiped Holmes for dispensing with-an authoritarian father. It seems cliaracteristic that in Ricketts v. Pennsylvania R., 153 F.2d 757, 760 (2d Cir. 1946) (Frank, J., concurring), Frank could conduct an extensive campaign against Williston and the objective the- 
more or less incidentally what were for them the conflicting strains in Holmes, but made no real effort to explain them. ${ }^{91}$ This perception of tension between the two sides of Holmes appears clearly in Walter Wheeler Cook's 1924 article The Logical and Legal Bases of the Conflict of Laws. ${ }^{92}$ Cook was an uncompromising legal reahst who made conflict of laws one of the mam battlegrounds of the war over legal reasoning. He described his undertaking as an effort to apply to conflict of laws the same method that had proved successful first im the physical and then in the social sciences. This method he characterized loosely as "inductive" and "experimental," as opposed to a procedure of deduction from fixed principles that only served, according to Cook, to block scientific advance. ${ }^{93}$ As he proceeded to apply his preferred approach, Cook drew heavily on Holmes, especially his perspective on law as prediction of judicial action and his view that deductive reasoning in law merely disguised essentially legislative choices. But Cook found when he examined conflicts opmions Holmes had written that they seemed fully consistent with Cook's principal targets-the First Restatement of Conflicts and the treatise written by the Restatement's guidimg gemus, Professor Joseph Beale of Harvard. ${ }^{94}$ How this could occur was a question that plainly worried Cook, but he left the problem unresolved.

It was not really necessary to resolve the problem. Quite naturally, the legal reahists and the Progressive and New Deal reformers-overlapping categories-were most concerned with the use that could be made of Holmes in their disputes with conservatives. It was true, as

ory of contract without noticing that Holmes had something to do with the objective theory. Rather, Holmes is pressed into service in support of the assault. $I d$. at $768 \&$ n.42, 770 n.50.

91. Cohen's views appear im M. CoHEN, Justice Holmes and the Nature of Law, im LAW AND the Social Order: Essays IN Legal Philosophy 198, 201 (1933): "Justice Holmes, despite the popular impression to the contrary, likewise begins with the old classical individuahistic economics, which assumes that the profit motive necessarily leads to a maximum productivity of desirable goods, that men render the greatest service when under the illusion of self-seeking"; and in M. CoHen, Oliver Wendell Holmes, in LAW AND the Social ORDER, supra, at 363, 367:

Justice Holmes's long and honourable record of dissenting opmions in cases where the courts have ignored the huinan rights of labour, and have unduly extended the rights of property and "freedom of contract," has given people the impression that he is something of a radical. This, however, is not the case. He is a firm believer in the régime of private property and the traditional economics. His dissenting opmions thus manifest a rare intellectual integrity that enables him to distinguish between his own opmions and that which the Constitution leaves to the legislature to determine.

For Laski's views, see infra note 95.

92. Cook, The Logical and Legal Bases of the Confict of Laws, 33 YALE L.J. 457 (1924), reprinted as W. COOK, The Logical Bases of the Confict of Laws, in THE LOGICAL AND LEGAL Bases of THE Conflict of LaWs 3 (1942).

93. Id. at $457-60$, reprinted in $\mathrm{W}$. CooK, supra note 92 , at 3-8.

94. For Cook's reliance on Holmes' jurisprudence, see id. at $465,476,487-88$, reprinted in W. CooK, supra note 92, at 15, 30-31, 44-46. For Cook's criticism of conficts opimons of Holmes, see id. at $479-81,482-83$, reprinted in W. CooK, supra note 92 , at 34-36, 38-40. 
Laski said, that "[m]uch of what passes to-day for radical doctrine he would . . . privately regard as politically unsound and economically unwise." 95 But though he had no "corpus of radical beliefs," he did have "a willingness to experiment with novelty in fundamentals."96 Thus he seemed "a radical to conservatives" and to radicals, "even in his rejection of their conclusions . . a powerful ally."97 Though the poimt was left unspoken, no doubt it also counted that these things were true of a descendant of New England Puritans, a Union officer wounded three times in the Civil War, and a Supreme Court Justice who continued his career as The Great Dissenter until 1931. Also, possibly not least, a graduate of Harvard College and Harvard Law School. Holmes remamed a fit companion for liberals as long as they talked the language of utility while conservatives employed a vocabulary of rights. In the post-New Deal generation the question what use Holmes was remained. However, beginning in the 1940's and increasingly thereafter reformers found more an embarassnient than an asset the man who said, "[F]or legal purposes a right is only the hypostasis of a prophecy-the imagimation of a substance supporting the fact that the public force will be brought to bear upon those who do things said to contravene it . . ..98 Liberals were discovering that rights should be emphasized a good deal and that they required a more secure foundation than the imagination. Holmes came to be ignored or disavowed, as seen in the debate between Mark Howe and Henry Hart and in Yosal Rogat's critique of Holmes.

As a public figure his career has followed a kind of evolutionary course. The environment of controversy over law has changed and in changing replaced one meaning of Holmes' work and personality with another. In a way he appears submitted to adaptive pressures as certain meanings are selected, then selected out when the environing climate of opmion shifts to open one ecological niche and close another. The appearance owes solnething to the fact that he never intended to satisfy reform opinion of any period. The program he formulated in writing The Common Law had quite different ainis. It ought to be possible to recover at least part of the historical Holmes to see what kind of world he had in view.

95. Laski, Mr. Justice Holmes, in MR. Justice Holmes 138, 153 (F. Frankfurter ed. 1931).

96. Id. at $152-53$.

97. Id. at 152.

98. Holmes, Natural Law, 32 HARv. L. Rev. 40, 42 (1918), reprinted in O.W. Holmes, supra note 24 , at 310,313 . 
II

\section{Holmes AND EVOLUTION}

I have used a metaphor of evolution in describing the course of Holmes' public reception. This was to provide a kind of ironic counterpoint to the achievement Holmes projected for himself. The Common Law is first of all an account of legal change, and its object in this respect is to exhibit the workings of Darwinian evolution in law.

This was the single most important influence that contributed to the making of the book, but there were others that ought to be mentioned. Among these was an idea that Holmes' friend and fellow Brahmin Henry Adams was introducing nito American historical writing in the 1870's-the idea of scientific history. This represented a reaction against what has been called literary history, exemplified by such people as George Bancroft and Francis Parkunan, the inspiring or upliftimg narrative of dramatic events. Scientific history, in contrast, stressed a critical spirit, attention to documents, a focus on nustitutions in a way calculated to reveal sequence and relation, and a cool and dry style. ${ }^{99}$ Another influence was the opinion then current in England and the United States, and to which Adams subscribed, that Anglo-Saxon political and legal institutions traced their origins to the allegedly democratic practices of Gerinaunc tribes. ${ }^{100}$ There was also the need, urgently felt im the 1870 's and later, to build a new conceptual structure for law as the rationalizing inupulse of Bentham and John Austin came to be felt more and more powerfully with the prolonged decay of the writ system. ${ }^{101}$ Reference should be made as well to the tradition of pre-Darwinian evolutionary writing about law that reached back to the eighteenth century. ${ }^{102}$ In the immediate background was Sir Henry Maine's Ancient Law, with its thesis that each legal system moved through a fixed order of inodes of effecting change in law-from legal fictions to equity to legislation.

There were what might be called negative influences. In claiming German origims for the common law, Holmes was rejecting an alternative source, which was Roman law. As Howe poimted out, the revival of Roman law carried out by the German historical school of the first part of the nineteenth century brought with it a conception of law informed by Gernan ideahism. ${ }^{103}$ Holmes was explicitly anti-Kantian

99. See W. JoRdy, HeNRY AdAMS: SCIENTIFIC Historian I-22 (1952).

100. See M. Howe, Justice Oliver Wendell Holmes: The Provino Years, 1870-1882, at 142-46 (1963); W. JORDY, supra note 99, at 35-37; E. SAMUEIs, THE YOuNo HENRY ADAMS $247-58$ (1948).

101. See M. Howe, supra note 100 , at $65-67$.

102. See P. Stein, LeaAl Evolution (1980).

103. See Howe, Introduction to O.W. HolmES, supra note 5, at xv-xvi. 
and anti-Hegelian. He wished to rule out certain ideas with an obvious bearing on, for example, criminal law and contract, such as the view that each person is to be treated as an end in himself rather than as an instrument of another's ends or that law aims to help realize the individual's autonomous will. In choosing a historical approach Holmes hoped to undermine what he considered an excessively rationalist treatment of law, as represented by John Austin. It was usually possible, Holmes believed, to invent grounds of policy to justify existing doctrine. ${ }^{104}$ If that same doctrine could be shown to liave originated in vanished circumstances, to have responded to concerns that had lost their imperative force, then plausible justifications could be made to appear imagmary and their power to prevent doctrinal renovation reduced. At the same time, historical demonstration that law changed in response to external forces would overthrow the assumption that seemed implicit in the work on contract of the then Dean of Harvard Law School, Christopher Langdell-the assumption that the test of a body of doctrine lay in the standard of internal consistency or coherence.

But agam, the theory of natural selection is the largest single influence on The Common Law. Holmes became a lawyer during the period in which Darwinism furnished a set of intellectual issues of overriding importance for educated people. He did not read The Origin of Species himself, but as he wrote Morris Cohen many years later, "the scientific way of looking at the world . . . was in the air." 105 During the early 1870's Holmes associated with a sunall group of men in Cambridge who were intensely and, as it turned out, productively involved with the problems Darwinism set for philosophy. This was the so-called Metaphysical Club, which included Charles Peirce and William James as well as Holmes. ${ }^{106}$ Holmes had no interest in the conflict of science and religion that Darwinism provoked, nor was he more than tangentially concerned with the debate over the philosophy of science that followed the appearance of Darwin's book. ${ }^{107}$ What did interest him was the possible apphication of Darwinist views to society. He is best seen, that is, as a kind of Social Darwinist. ${ }^{108}$

What kind of Social Darwinist Holmes was is suggested by an alternative characterization-he could also be said to have held a version of pragmatism. The origins of pragmatism lie in the efforts of the

104. O.W. HoLMES, supra note 5 , at 8.

105. Cohen, The Holmes-Cohen Correspondence, 9 J. Hist. IDEAs 3, 14 (1948).

106. See B. Kukilck, The Rise of American Philosophy 47-54 (1977); P. Wiener, Evolution AND the Founders of Pragmatism 18-30 (1949).

107. See D. Hull, Darwin aNd His CRITICs (1973).

108. That "Social Darwinist" does not identify any single set of views but rather a number of such sets coines out in R. Hofstadter, Social Darwinism in AMERICAN Thought (1944). 
Metaphysical Club's members to come to terms with the new science, which had put all in doubt. One of them, Chauncey Wright, tried to show how evolution could have produced the consciousness of self that human beings exhibit. ${ }^{109}$ Others were more concerned with the evolution of the products of self-consciousness, beliefs and ideas. One of the lawyer-members of the Club, Nicholas St. John Green, emphasized, according to Peirce, a definition of belief as "that upon which a man is prepared to act."110 From this Peirce developed the so-called pragmatic maxim, very crudely stated as the view that the meaning of an idea consists of the sum of its conceivable practical consequences. Holmes' definition of law as prediction of what the courts will do in fact may be read as an application to law of one of Peirce's formulations of the maxim. ${ }^{111}$ This was that an experimentalist understands an assertion "as meaning that if a given prescription for an experiment ever can be and ever is carried out $\mathrm{m}$ act, an experience of a given description will result, or else he will see no sense at all in what you say."112 From a theory of meaning, pragmatism became, with William James, a theory of value; the test of the utility or value of an idea or behef hes in the consequences that follow from acting upon it. There is here a clear parallel to the Darwinian position that natural selection submits variations in species to the test of fitness, with survival hinging upon the outcome.

James developed his version of pragmatism in searching for a means of affirming rehgious and moral beliefs. This divided him from Holmes, who had no use for religion whatever. He praised personal commitment and struggle but evidently for their own sake, not because they had any connection to a larger end. His attitude appears in a Memorial Day speech he gave in 1895 , The Soldier's Faith, ${ }^{113}$ in which war is to be taken as a metaphor for human life. "[T]he faith is true and adorable," he said, "which leads a soldier to throw away his life im

109. See C. WRIGHT, Evolution of Self-Consciousness, in PHILosophiCAL Discussions 199 (1877). On Wright, see B. KuKLICK, supra note 106, at 63-79; E. MADDEN, ChAUNCEY Wright AND THE Foundations of Pragmatism (1963); P. WiENER, supra note 106, at 31-69, 207-12.

110. Fisch, Alexander Bain and the Genealogy of Pragmatism, 15 J. HIST. IDEAS 413, 413 (1954) (qnoting 5 C.S. Peirce, The Collected Papers of Charles Sanders Peirce \ 5.12 (C. Hartshorne \& P. Weiss eds. 1934)). On Green, see P. WIENER, stpra note 106, at 152-71, 231-34; Frank, A Conflict with Oblivion: Some Observations on the Founders of Legal Pragmatism, 9 RutGers L. Rev. 425 (1954).

111. See Fisch, Justice Holmes, The Prediction Theory of Law, and Pragmatism, 39 J. PHIL. 85 (1942).

112. 5 C.S. Peirce, The Collected Papers of Charles Sanders Peirce $\{5.411$, at 273 (C. Hartshorne \& P. Weiss eds. 1934). Alternatively, "[c]onsider what effects, that inight conceivably have practical bearings, we conceive the object of our conception to have. Then, our conception of these effects is the whole of our conception of the object." Id. \ 5.402, at 258 .

113. Reprinted in The Occasional Speeches of Justice Oliver Wendell Holmes 73 (M. Howe ed. 1962). 
obedience to a blindly accepted duty, in a cause which he hittle understands, in a plan of campaign of which he has no notion, under tactics of which he does not see the use."114 On principle Holmes saw no inore significance in the human race than in a grain of sand. ${ }^{115}$ The only standard by which to measure human life lay in the physical laws that linked cause to effect. When he was wounded at Ball's Bluff and beheved he was dymg, he thought, "Then came in iny Philosophy-I am to take a leap in the dark-but now as ever I believe that whatever shall happen is best-for it is in accordance with a general law-and good \& universal (or general law) are synonymous terns in the universe."116 According to the bleakly Malthusian faitli that Darwin confirmed for him, all human effort finds its sanction in the struggle for existence.

On this view law becounes an adaptive mechanism that groups of people use to advance their interests in the struggle for existence. Holmes said exactly this in a brief comment he published in 1873. A controversy had arisen in England over the prosecution of a group of gas stokers who had gone on strike. In joiming the discussion Holines wrote this:

The struggle for life, undoubtedly, is constantly putting the interests of inen at variance with those of the lower animals. And the struggle does not stop in the ascending scale with the inonkeys, but is equally the law of human existence. Outside of legislation this is undeniable. It is mitigated by sympathy, prudence, and all the social and inoral qualities. But in the last resort a man rightly prefers his own interest to that of his neighbors. And this is as true in legislation as in any other form of corporate action. All that can be expected from inodern improvements is that legislation should easily and quickly, yet not too quickly, modify itself in accordance with the will of the de facto supreme power in the community, and that the spread of an educated sympathy should reduce the sacrifice of minorities to a minimuin. But whatever body may possess the supreme power for the moment is certain to have interests inconsistent with others which have competed unsuccessfully. The more powerful interests must be more or less reflected in legislation; which, like every other device of inan or beast, must tend in the long run to aid the survival of the fittest. ${ }^{117}$

This is the background of The Common Law. The idea of evolution remams in the background in the book but serves to organize it in two ways. First, law is presented metaphorically, as itself an organic

114. Id at 76.

115. Holmes, supra note 98 , at 44 , reprinted in O.W. Holmes, supra note 24 , at 316 .

116. TOUChed With Fire: CiviL War LetTers and Diary OF OlIVER WeNDEll Holmes, JR. 1861-1864, at 28 (M. Howe ed. 1947) (emphasis in original).

117. Holmes, The Gas-Stokers' Strike, 44 HARV. L. REv. 795, $795-96$ (1931), reprinted from 7 AM. L. REv. 583 (1873). 
form that evolves. The title of the first lecture-Early Forms of Liability-alludes to the fossil remains of the predecessors of existing species. The content of the lecture-how seemingly unrelated legal rules chosen as if by chance can be traced to a common origin in primitive notions of vengeance-carries out the same comparison. The same is true of the succeeding two lectures, which show how the primitive impulse of revenge has been transformed into the rational aim of prevention of socially defined harm. The lecture on the history of contract demonstrates how consideration arose as social need selected among variations in doctrime random with respect to the eventual function of furnishing a test for enforceability of promises. The point could be illustrated further, but it is less important than the other use Holmes made of the idea of evolution. This was to present Holmes' view of the doctrines that were more and more tending to advance the interests of the supreme power in the community.

Who was it that Holmes thought held the supreme power in the community? The answer seeins to be, the ordinary prudent and intelligent person. It was his understanding and capacity that provided the test of liability im tort and criminal law and his linguistic conventions that supplied the standard of obligation in contract. Just as years later Holmes deferred to the average person's desires as expressed in legislation, so in The Common Law he tried to describe a legal world congemal to the average man. However, what that person was about in the 1860's and 1870's when Holmes was forming his opinions very likely changed between then and now. Holmes wrote The Common Law at the end of the period during which one of the nnain objectives of American law was to facilitate what lias been called "the release of creative human energy." 118 In a politically democratic country descended from England, rich in natural resources but short of labor and capital, that meant an attempt to proinote economic growth by mamtaming a market in which individuals were free-if not compelled-to invest their capital, skills, and labor in coinpetition for economic advantage. The function of law in this setting was to provide the structure on which the market depended, to prevent theft and fraud and to enforce contracts. These considerations explaim what Holmes evidently regarded as the most important theme of The Common Law, the shift in standards of liability from the subjective, internal, and moral to the objective, external, and fornal. By an "objective" standard Holmes ineant in tort and criminal law what was inorally blameworthy in the

118. This phrase is James Willard Hurst's term for the process through which promotion of economic growth was pursued over the first three-quarters of the nineteenth century. J. HURST, LaW and the Conditions of Freedom in the Nineteenth-Century United States 5 (1956). 
reasonable and prudent person, in contract law what the ordinary speaker of English would understand the words to mean under the circumstances. A higher standard would be, as Holmes said, too hard for the community to bear. ${ }^{119}$ A lower standard would reduce the security witl whicl the average person could conduct his affairs, thereby dampening individual initiative. A consequence of the objective standard was of course that a person of less than average capacity and understanding might be convicted of a crime or required to pay damages for a tort though he was morally ninocent, or might be held bound by a contract that he never intended to enter. Holmes fully recognized this consequence. The Civil War, however, had accustomed him to death, and as he often said, "[e]very society is founded on the death of men." 120

Even while Holmes was colnposing the lectures that went into The Common Law, the world he had in mind was changing. With the great railroad strike of 1877 there erupted into view social tensions reflecting urgent, increasingly belligerent concern over the distribution of wealth. In the world of large organizations that caine into being at the end of the nineteenth century, competition in the market took on a new ineaning. Holmes saw this change as clearly as anyone else, and he took account of it in various ways. For exainple, he seeins to have accepted workers' compensation, recognizing that in the field of industrial injury his conception of tort law had been repealed by the law of large nuinbers-that is, by the logic of spreading risks. ${ }^{121}$ But he never systematically reconsidered his views of the common law.

\section{CONCLUSION}

It is hard to resist the inference that Holmes had his own book in mind in saying, as he often did, that philosophers' systems cruunble, leaving only scattered insights. His overall view has not seemed persuasive for a long time. Many of the ideas he advocated have been influential-indeed, they sometimes influenced people on opposite sides of the saine issue. One idea especially remains common today. Early in Holmes' career he occasionally spoke as though legal change lacked conscious direction, as if the natural selection of social experience operated on randoin variations in legal doctrine. Eventually he came to the belief, put most strongly in The Path of the Law but already

119. O.W. Holmes, supra note 5 , at 42 .

120. Book Notices, supra note 87 , at 181 .

121. Compare the views expressed in O.W. HolmEs, supra note 5, at 77-78, with those set out in Holmes, The Path of the Law, 10 HARV. L. REv. 457, 467 (1897), reprinted in O.W. Holmes, supra note 24, at 183, and Holmes' concurring opinion in the Arizona Employers' Liability Cases, 250 U.S. 400, 433 (1919) (Holmes, J., concurring). 
present in his 1880 lectures, that we can replace chance with rational control, dehiberately changing law to help make the world we want. This Promethean gift of self-awareness warms and burns us still. 